\title{
Towards the Concerted Study of Caddo Origins
}

Timothy K. Perttula

Heritage Research Center, Stephen F. Austin State University

Follow this and additional works at: https://scholarworks.sfasu.edu/ita

Part of the American Material Culture Commons, Archaeological Anthropology Commons, Environmental Studies Commons, Other American Studies Commons, Other Arts and Humanities Commons, Other History of Art, Architecture, and Archaeology Commons, and the United States History Commons

Tell us how this article helped you.

This Article is brought to you for free and open access by the Center for Regional Heritage Research at SFA ScholarWorks. It has been accepted for inclusion in Index of Texas Archaeology: Open Access Gray Literature from the Lone Star State by an authorized editor of SFA ScholarWorks. For more information, please contact cdsscholarworks@sfasu.edu. 


\section{Towards the Concerted Study of Caddo Origins}

Creative Commons License

(c) (i) (8)

This work is licensed under a Creative Commons Attribution-NonCommercial 4.0 International License 


\title{
Towards the Concerted Study of Caddo Origins
}

\author{
Timothy K. Perttula
}

The study of the origins of any people from an archaeological perspective is a considerable undertaking, one that may task the efforts and thoughts of a multitude of people, probably from several disciplines. After the talking and discussion in the 2008 East Texas Caddo Research Group (ETCRG) meeting about Caddo origins, how do we proceed from here on out to arrive at a more comprehensive understanding of Caddo origins? For the purposes of discussion, I am assuming that the ETCRG participants agree that the concerted study of Caddo origins is an issue and research problem worth undertaking.

I recently had occasion to read "Zuni Origins: Toward a New Synthesis of Southwestern Archaeology" (edited by David A. Gregory and David R. Wilcox, 2007, University of Arizona Press) ${ }^{1}$ to see if their consideration of origins may have some relevant and programmatic suggestions to offer that could serve Caddo archaeologists and ETCRG participants well in our future studies. I think they offer some suggestions and an approach well-worth further consideration for future ETCRG meetings as well as for other meetings and avenues of study concerning Caddo archaeology.

1. In any consideration of Caddo origins, there will be a need to think macro-regionally, at multiple spatial and temporal scales. Synthesis needs to be accomplished at many scales, and is a continuing goal;

2. Large-scale contexts for considerations of language (i.e., changes in the linguistic landscape), culture, and environments are important, as well as considerations of what constitutes cultural identity in the case of the Caddo(s);
3. construct expectations about where to look for antecedents of the Caddo; where does the Caddo tradition fit in the development of Mississippian/Southeastern societies; what are the relationships between the Caddo and neighboring groups;

3a. paralleling the compilation of the Coalescent Communities Database (Wilcox et al. 2007:165-209), develop methods to arrive at a more realistic demographic estimate of population trends and the relative distribution and abundance of Caddo populations on the landscape through time, and their changes through time; what would serve as a proxy for demography in the Caddo archaeological record?

4. determine how distinctions based on material culture can be employed in modern archaeological contexts to be organizationally and archaeologically meaningful;

5. Conceptualize the origins issue in terms of a research design of related general problem domains and specific research questions. Jeff's handout has made a very good start in that direction.

How might we then proceed? The Zuni Origins book advocates a research approach that should work well, and can be developed out of the ETCRG framework, and that is:

- bring a diverse set of folks together that are conducting or are wanting to conduct, relevant Caddo research, or have information they can contribute to the larger issues, to consider the specific research questions and problem domains mentioned above.

1. Something to consider: There has been a suggestion made by several linguists that there is an ancient linguistic relationship between Caddoan and Keresan, a Southwestern language group in western New Mexico, and Zuni, more closely related to Keresan. Hill (2007:21, fn 2) suggests that the relationship is a remote one, probably that of populations and languages that split more than 7000-8000 years ago. 
- Such a group could meet in an advanced seminar setting, or some other setting where a small and focused group of folks can meet, as the mechanism to achieve new syntheses of those particular Caddo research problems and issues. Such a setting is one where research findings are presented and discussed.

- Such a framework could proceed along the following lines: (a) key individuals or a team of Caddo archaeologists develop problem domains and research questions (i.e., a research design) that are relevant to a consideration of an issue such as Caddo origins and put the issue in its broadest context; (b) bring together people as presenters and discussants who can provide scale and diversity in research perspectives to suitably address the problem domains and research questions; (c) ask these people to prepare written papers prior to the advanced seminar meeting, or serve as discussants, on some aspect of the research design, then present synopses and conduct discussions at the meeting itself on problem domains and research questions - the seminar serving as a sounding board for findings, hypotheses, and conclusions; and (d) after the advanced seminar meeting, these same individuals (and perhaps others that can be enlisted) prepare final versions of papers that have taken into account the various perspectives aired at the seminar itself. Publications outlets are sought, or working documents prepared for future use.

- From there, meetings to further develop or pursue related research issues, or examine in more depth a particular research problem concerning Caddo origins, could be held at a Caddo Conference, a future ETCRG meeting, or some other venue. 